\title{
Lutein Specific Relationships among Some Spectrophotometric and Colorimetric Parameters of Chicken Egg Yolk
}

\author{
Khan M. S. Islam ${ }^{1}$, Mahmoud Khalil ${ }^{2}$, Klaus Männer ${ }^{3}$, Jens Raila ${ }^{2}$, \\ Harshadrai Rawel ${ }^{2}$, Jürgen Zentek ${ }^{3}$ and Florian J. Schweigert ${ }^{2}$ \\ ${ }^{1}$ Department of Animal Nutrition, Bangladesh Agricultural University, Mymensingh, 2202, Bangladesh \\ ${ }^{2}$ Institute of Nutritional Science, University of Potsdam, Arthur-Scheunert-Allee 114-116, 14558 Nuthetal, Germany \\ ${ }^{3}$ Institute of Animal Nutrition, Freie University, Königin-Luise-Str. 49, 14195 Berlin, Germany
}

\begin{abstract}
Lutein is an essential dietary carotenoid with health benefits and is inter alia responsible for the colouration of egg yolk. The relationship between lutein accumulation and egg yolk colouration was therefore studied in more detail. After feeding a low-luteine diet for 21 days, 14 birds (Lohmann brown hens aged 20 weeks) were fed a diet containing marigold ( $80 \mathrm{mg}$ lutein $/ \mathrm{kg}$ feed) and 14 other birds were fed a diet containing oleoresin (45 mg lutein/ $\mathrm{kg}$ feed) for 21 days; for both groups of birds, this feeding period was followed by withdrawal for 21 days. The Roche Yolk Colour Fan (RYCF) score ( 0 to 15 , where higher values denote greater colour intensity; $\left.\mathrm{R}^{2}=0.87 ; P<0.01\right)$ and redness $\left(\mathrm{R}^{2}=0.89 ; P<0.01\right)$ increased with increasing lutein content of egg yolk. Total carotenoid content had a poor relationship with lightness $\left(\mathrm{R}^{2}=0.13 ; P>0.05\right)$ and yellowness $\left(\mathrm{R}^{2}=0.12 ; P>0.05\right)$ of the yolk. It may be concluded that increased lutein is potentially responsible for an increased RYCF score and redness ( $\mathrm{a}^{*}$ ), but decreased yellowness $\left(b^{*}\right)$ and lightness $\left(\mathrm{L}^{*}\right)$, of egg yolk.
\end{abstract}

Key words: carotenoid, HPLC, iCheck, lutein, spectrophotometry, yolk

J. Poult. Sci., 54: 271-277, 2017

\section{Introduction}

Lutein is one of the major xanthophylls present in egg yolk, and is responsible for pigmentation of egg yolks related to consumer perception (Karunajeeva et al., 1984). Lutein content in table eggs is $0.29 \mathrm{mg} / \mathrm{egg}$, and eating 1.3 eggs per day for 4.5 weeks increased blood levels of lutein by $50 \%$ owing to its high bioavailability (Handelman et al., 1999). This pigment accumulates in the macular region of the human retina and is responsible for the prevention of agerelated macular degeneration and for the prevention of cancer (Bone et al., 1988; Handelman et al., 1988; Seddon et al., 1994; Mayne, 1996; Landrum et al., 1997). Because lutein is not synthesized in the human body, obtaining the pigment through diet is essential (Krinsky, 1993; Britton, 1995). Considering that lutein is a valuable carotenoid that accumulates in egg yolks and is responsible for their colouration, it is necessary to establish a quantitative relationship among lutein and coloration to determine the quality of eggs.

The main established method to determine the content of

Received: April 17, 2016, Accepted: February 12, 2017

Released Online Advance Publication: June 25, 2017

Correspondence: Prof. Dr. Khan Md. Shaiful Islam, Department of Animal Nutrition, Bangladesh Agricultural University, Mymensingh-2202, Bangladesh. (E-mail: kmsislam1@yahoo.com) individual carotenoids including lutein is high-performance liquid chromatography (HPLC) (Williams, 1992; Hamilton, 1992). An alternative method that is laboratory-independent and requires very limited technical experience has recently been introduced, and this method utilizes iCheck (iCheck, BioAnalyt GmbH, Germany) for the determination of total carotenoid content (Schweigert et al., 2010; Islam and Schweigert, 2015). On other hand, the degree of coloration may be measured directly by the Roche Yolk Colour Fan (RYCF), which is routinely using in the egg industry (Vuilleumiler, 1969). Colour is measured by using the three coordinates of CIELAB, representing the lightness of the colour $\left(\mathrm{L}^{*}=0\right.$ yields black and $\mathrm{L}^{*}=100$ indicates diffuse white), its position between red/magenta and green ( $\mathrm{a}^{*}$, negative values indicate green while positive values indicate magenta), and its position between yellow and blue ( $b^{*}$, negative values indicate blue and positive values indicate yellow) (Hunter, 1948a, b).

There are several studies on the correlation between colour parameters and carotenoid content in different vegetables such as pepper (Reeves, 1987), tomato (Arias et al., 2000), sweet potato (Ameny and Wilson, 1997) and squash (Seroczynska et al., 2006). Interestingly, the authors of those studies differ in their opinions on the reliability of colorimetric analysis in estimating carotenoid content and 
concentration. Hence, the present study was designed to draw a clear quantitative relationship between lutein content and the different colour parameters of egg yolks that were obtained from chickens fed with lutein-enriched diets. These diets were achieved by supplementation of chicken feed with marigold (Tagetes erecta L.) or oleoresin (dark brown viscous liquid extracted from marigold), which are two good sources of lutein.

\section{Materials and Methods}

\section{Preparation of Test Substances}

Soybean oil and oleoresin (Oleoresin, BioExtract, Bangalore, India) were mixed using a magnetic stirrer (VarioMag poly $15, \mathrm{H}+\mathrm{P}$, Labortechnik, Germany) for $15 \mathrm{~min}$, followed by ultrasonic treatment (Sonorex AK100, Bandelin, Germany) for $10 \mathrm{~min}$. The mixtures were refrigerated until they were mixed into the feed on the following day. Marigold powder is commercially available in local markets in powder form.

\section{Birds and Diet Formulation}

For this study, 28 egg-laying Lohmann brown hens aged 20 weeks were used. Egg production by these hens was $95 \%$, and the hens consumed $120 \mathrm{~g}$ feed/day on average. Birds were fed a wheat barley-based low lutein diet for a period of 21 days (Table 1).

\section{Feeding of Hens and Collection of Samples}

After 21 days of a low-lutein diet, the birds were divided into two groups (each $n=14$ ) for 21 days: the marigoldsupplemented group ( $80 \mathrm{mg}$ lutein $/ \mathrm{kg}$ feed) or the oleoresinsupplemented group ( $45 \mathrm{mg}$ lutein $/ \mathrm{kg}$ feed). Both treatments were followed by a 21-day withdrawal period, where the birds were fed a lutein-free diet. During this 42-day period, the feed amounted to $120 \mathrm{~g} \cdot \mathrm{day}^{-1} \cdot \mathrm{bird}^{-1}$, and the birds had a free access to drinking water. The birds were checked daily during the study to ensure an adequate supply of feed and water, and a veterinarian monitored health statuses. The Frei University Berlin Animal Care Committee approved all animal procedures. Eggs were collected starting on the first day of lutein-enriched diets and were followed by collections on day $7,14,21,28,35$ and 42 . In total, 68 eggs from marigold-supplemented group and 60 eggs from oleoresinsupplemented group were obtained during this study.

\section{Yolk Colour Parameters}

After breaking the egg shell yolks were placed in a glass Petri dish $(100 \times 12 \mathrm{~mm})$ over a white background, and colour was determined visually by 5 individuals using the RYCF. The egg yolk colour was also determined using a Minolta Chroma-meter (CR-300, Minolta Camera Co., Ltd. Osaka 541, Japan) in the CIE L* $\mathrm{a}^{*} \mathrm{~b}^{*}$ space. According to the manufacturer provided instructions the $\mathrm{L}^{*}$ value indicates the lightness, representing dark to light (0 to 100); the redness $\left(a^{*}\right)$ value indicates the degree of red or green, with a higher positive $\mathrm{a}^{*}$ value indicating more red; the yellowness $\left(b^{*}\right)$ value indicates the degree of yellow/blue, with a higher positive $\mathrm{b}^{*}$ value indicating more yellow.

\section{Extraction of Total Carotenoid and Lutein from Egg Yolk}

The iCheck ${ }^{\circledR}$ (BioAnalyt GmbH, Teltow, Germany) method consists of a disposable container representing an extraction and measuring unit, the iEx, and a battery-driven hand-held photometer. A pre-determined amount of $0.40 \mathrm{~g}$ egg yolk was diluted to a final weight of $2.00 \mathrm{~g}$ with dilution buffer. Exactly $400 \mu l$ of the diluted egg yolk was injected into the extraction vial. Thereafter, the vial was shaken vigorously for $10 \mathrm{~s}$ and left for complete phase separation for at least 5 min. This procedure completely extracts all of the carotenoids present in the sample into the upper organic phase of

Table 1. Composition of layer diet (NRC, 1994)

\begin{tabular}{lrlr}
\hline \hline \multicolumn{1}{c}{ Ingredients (\%) } & \multicolumn{1}{c}{$\%$} & Chemical composition & $\mathrm{g} / \mathrm{Kg}$ \\
\hline Wheat & 60.42 & $\mathrm{ME}_{\mathrm{N}}(\mathrm{MJ} / \mathrm{kg})$ & 11.04 \\
Soybean meal (48 CP) & 16.00 & Crude protein & 160.60 \\
Calcium carbonate & 8.50 & Lysine & 7.50 \\
Barley & 10.00 & Methionine & 3.40 \\
Soy oil & 2.05 & Methionine + Cystine & 6.40 \\
Premix* & 1.20 & Threonine & 5.00 \\
Arbocel & 1.00 & Tryptophan & 1.90 \\
Monocalcium phosphate & 0.75 & Crude fiber & 32.10 \\
DL-Methionine & 0.08 & Crude fat & 35.70 \\
& & Calcium & 34.40 \\
Total & 100 & Phosphorus & 5.10 \\
& & Sodium & 1.80 \\
\hline
\end{tabular}

* Contents per kg Premix: 400000 U Vit. A; 40000 U Vit. $D_{3} ; 8000 \mathrm{mg}$ Vit. E ( $\alpha$ Tocopherole acetate); $300 \mathrm{mg}$ Vit. $\mathrm{K}_{3} ; 250 \mathrm{mg}$ Vit. $\mathrm{B}_{1} ; 250 \mathrm{mg}$ Vit. $\mathrm{B}_{2} ; 2500 \mathrm{mg}$ Nicotinic acid; $400 \mathrm{mg}$ Vit. $\mathrm{B}_{6} ; 2000 \mu \mathrm{g}$ Vit. $\mathrm{B}_{12} ; 25000 \mu \mathrm{g}$ Biotin; $1000 \mathrm{mg}$ calcium pantothenate acid; $100 \mathrm{mg}$ Folic acid; $80000 \mathrm{mg}$ Choline chloride; $5000 \mathrm{mg}$ Zn (Zinc oxide); $2000 \mathrm{mg}$ Fe (Iron carbonate); $6000 \mathrm{mg} \mathrm{Mn} \mathrm{(Manganese} \mathrm{oxide);}$ $1200 \mathrm{mg} \mathrm{Cu}$ (Copper sulfate-pentahydrate); $45 \mathrm{mg} \mathrm{J}$ (Calcium jodate; $30 \mathrm{mg} \mathrm{Co}$ (Cobalt- (II)-sulfate-heptahydrate); $35 \mathrm{mg}$ Se (Sodium selenite); $130 \mathrm{~g} \mathrm{Na}$ (Sodium chloride); $55 \mathrm{~g} \mathrm{Mg}$ (Magnesium oxide). 
the vial. The concentration was measured in the portable photometer and final concentration $(\mathrm{mg}$ carotenoid/kg egg yolk) was calculated based on sample weight and final buffer weight.

To measure lutein in egg yolks, the cap of the iCheck ${ }^{\circledR}$ vial was removed and an aliquot of $200 \mu l$ organic phase was transferred to a $4-\mathrm{m} l$ tube and incubated at $37^{\circ} \mathrm{C}$ under $\mathrm{N}_{2}$ to allow the sample to dry. The dried sample was dissolved in $200 \mu l$ isopropanol, vortexed, and treated in the ultrasonic bath for $5 \mathrm{~min}$. Finally, the sample was centrifuged for $5 \mathrm{~min}$ at $2000 \times g$ (Thermo Fischer Scientific Haraeus Labofuge 200, Berlin, Germany) to be used in high-performance liquid chromatography (HPLC).

\section{HPLC}

The determination of relevant carotenoid (lutein and zeaxanthin) content present in yolk was conducted on a HPLC system (Waters GmbH, Eschborn, Germany) equipped with a binary pump system, a degasser, an auto-sampler, and a diode array detector (DAD). The separation was carried out with a C30 analytical column, $250 \times 3 \mathrm{~mm}, 5 \mu \mathrm{m}$ (YMC Europe $\mathrm{GmbH}$, Dinslaken, Germany). The column temperature was maintained at $20^{\circ} \mathrm{C}$. The binary mobile phase consisted of methanol-ammonium acetate, $0.4 \mathrm{~g} / \mathrm{l}$ in distilled water (9: 1, v/v; solvent A) and methyl-t-butyl ether-methanol-ammonium acetate, $0.1 \mathrm{~g} / \mathrm{l}$ in distilled water $(90: 8: 2, \mathrm{v} / \mathrm{v} / \mathrm{v}$, solvent B). The flow rate was kept at $0.2 \mathrm{ml} / \mathrm{min}$. Detection was conducted at $450 \mathrm{~nm}$. Elution was carried out with a gradient program: $100,93,85,80,75,45,13,7,1$ and $1 \%$ at, 0,1 , $2,3,11,21,29,32,33,45,45.1$ and 60 minutes, respectively, for solvent A.

\section{Statistical Analysis}

Data were organized using the Microsoft Excel program and mean values of different experimental groups were compared by using one-way ANOVA following Tukey's test as described in Steel and Torrie (1990). Statistical analysis was conducted by applying the Minitab software (Minitab, 1998).

\section{Results}

\section{Total Carotenoid, Lutein, and Zeaxanthin Content in Egg Yolks}

Total carotenoid, lutein, and zeaxanthin content in egg yolks during supplementation and withdrawal of lutein in the marigold- and oleoresin-supplemented groups is shown in Table 2. The zeaxanthin content of the egg yolks was very low throughout the experiment, which indicates that the major part of total carotenoid is lutein and suggests that the colorimetric parameters derived in this experiment are luteinspecific.

Although the feed for the marigold-supplemented group contained about double the amount of lutein, its effect on the total carotenoid content of egg yolks appears to be lower compared to that in the oleoresin-supplemented group during supplementation and wash-out periods (Table 2a,b). The total carotenoid content corresponds to the concentration of lutein and zeaxanthin in the egg yolk throughout the feeding, where also the major part of the carotenoids is again lutein; this is also indicated by the relationship of their contents in both marigold- and oleoresin-supplemented groups $\left(\mathrm{R}^{2}=\right.$ $0.99 ; P<0.01$; Fig. 1$)$.

After feeding a low-lutein diet for a period of 21 days, the lutein concentration of egg yolk observed was $1.57 \pm 0.37 \mathrm{mg}$ lutein $/ \mathrm{kg}$ egg yolk (Table $2 \mathrm{a}, \mathrm{b})$. The lutein level increased rapidly when lutein-enriched diet was applied, and the highest values were achieved on day 14 for total carotenoid and lutein levels in marigold- and oleoresin-supplemented groups. Subsequent withdrawal of lutein required 14 days to return total carotenoid and lutein content to normal. These results document that an intervention of 14 days with luteinenriched feed is enough to produce eggs with a high content of biologically relevant and comparatively more bioavailable lutein.

\section{Colorimetric Parameters of Yolk}

As recorded for total carotenoids, RYCF scores and redness $\left(a^{*}\right)$ of yolk were higher in the marigold-supplemented group than in the oleoresin-supplemented group (Table 3a,

Table 2. Total carotenoid, lutein and zeaxanthin content of egg yolk (a) Marigold group ( $80 \mathrm{mg}$ lutein $/ \mathrm{kg}$ feed)*

(b) Oleoresin group (40 mg lutein/ $\mathrm{kg}$ feed)*

\begin{tabular}{cccc|ccc}
\hline \hline Days & $\begin{array}{c}\text { Carotenoid } \\
(\mathrm{mg} / \mathrm{kg})\end{array}$ & $\begin{array}{c}\text { Lutein } \\
(\mathrm{mg} / \mathrm{kg})\end{array}$ & $\begin{array}{c}\text { Zeaxanthin } \\
(\mathrm{mg} / \mathrm{kg})\end{array}$ & $\begin{array}{c}\text { Carotenoid } \\
(\mathrm{mg} / \mathrm{kg})\end{array}$ & $\begin{array}{c}\text { Lutein } \\
(\mathrm{mg} / \mathrm{kg})\end{array}$ & $\begin{array}{c}\text { Zeaxanthin } \\
(\mathrm{mg} / \mathrm{kg})\end{array}$ \\
\hline 1 & $3.1 \pm 0.7^{\mathrm{a}}$ & $1.58 \pm 0.19^{\mathrm{a}}$ & $0.14 \pm 0.03^{\mathrm{a}}$ & $3.2 \pm 0.7^{\mathrm{a}}$ & $1.57 \pm 0.28^{\mathrm{a}}$ & $0.14 \pm 0.02^{\mathrm{a}}$ \\
7 & $9.4 \pm 4.3^{\mathrm{b}}$ & $7.14 \pm 3.54^{\mathrm{b}}$ & $0.27 \pm 0.10^{\mathrm{b}}$ & $9.1 \pm 3.2^{\mathrm{b}}$ & $6.70 \pm 2.61^{\mathrm{bc}}$ & $0.39 \pm 0.13^{\mathrm{bc}}$ \\
14 & $34.6 \pm 3.9^{\mathrm{e}}$ & $23.43 \pm 3.30^{\mathrm{c}}$ & $0.75 \pm 0.10^{\mathrm{c}}$ & $30.3 \pm 6.0^{\mathrm{e}}$ & $18.99 \pm 4.06^{\mathrm{e}}$ & $0.88 \pm 0.21^{\mathrm{e}}$ \\
21 & $33.2 \pm 4.3^{\mathrm{e}}$ & $21.65 \pm 3.16^{\mathrm{c}}$ & $0.67 \pm 0.11^{\mathrm{c}}$ & $27.5 \pm 6.5^{\mathrm{e}}$ & $17.10 \pm 3.99^{\mathrm{de}}$ & $0.77 \pm 0.18^{\mathrm{de}}$ \\
28 & $16.1 \pm 4.5^{\mathrm{c}}$ & $10.44 \pm 2.27^{\mathrm{b}}$ & $0.34 \pm 0.06^{\mathrm{b}}$ & $18.5 \pm 2.5^{\mathrm{c}}$ & $12.30 \pm 2.30^{\mathrm{cd}}$ & $0.51 \pm 0.07^{\mathrm{cd}}$ \\
35 & $2.4 \pm 1.0^{\mathrm{a}}$ & $1.69 \pm 0.55^{\mathrm{a}}$ & $0.11 \pm 0.03^{\mathrm{a}}$ & $2.8 \pm 3.1^{\mathrm{ab}}$ & $2.13 \pm 1.51^{\mathrm{ab}}$ & $0.15 \pm 0.09^{\mathrm{ab}}$ \\
42 & $1.5 \pm 0.3^{\mathrm{a}}$ & $1.12 \pm 0.06^{\mathrm{a}}$ & $0.10 \pm 0.01^{\mathrm{a}}$ & $1.9 \pm 0.5^{\mathrm{ab}}$ & $1.24 \pm 0.14^{\mathrm{ab}}$ & $0.10 \pm 0.01^{\mathrm{a}}$ \\
\hline
\end{tabular}

$\mathrm{a}, \mathrm{b}, \mathrm{c}, \mathrm{d}$ Values with the different superscripts in the same column differ significantly $(P<0.05)$;

* Number of eggs from marigold group is 68 (number of eggs in day 1, 7, 14, 21, 28, 35, 42 is 14, 13, 14, 12, 5, 5, 5, respectively) and number of eggs from oleoresin group is 60 (number of eggs in day1, 7, 14, 21, 28, 35, 42 is $14,11,14,11,3$, 4,3 , respectively). 

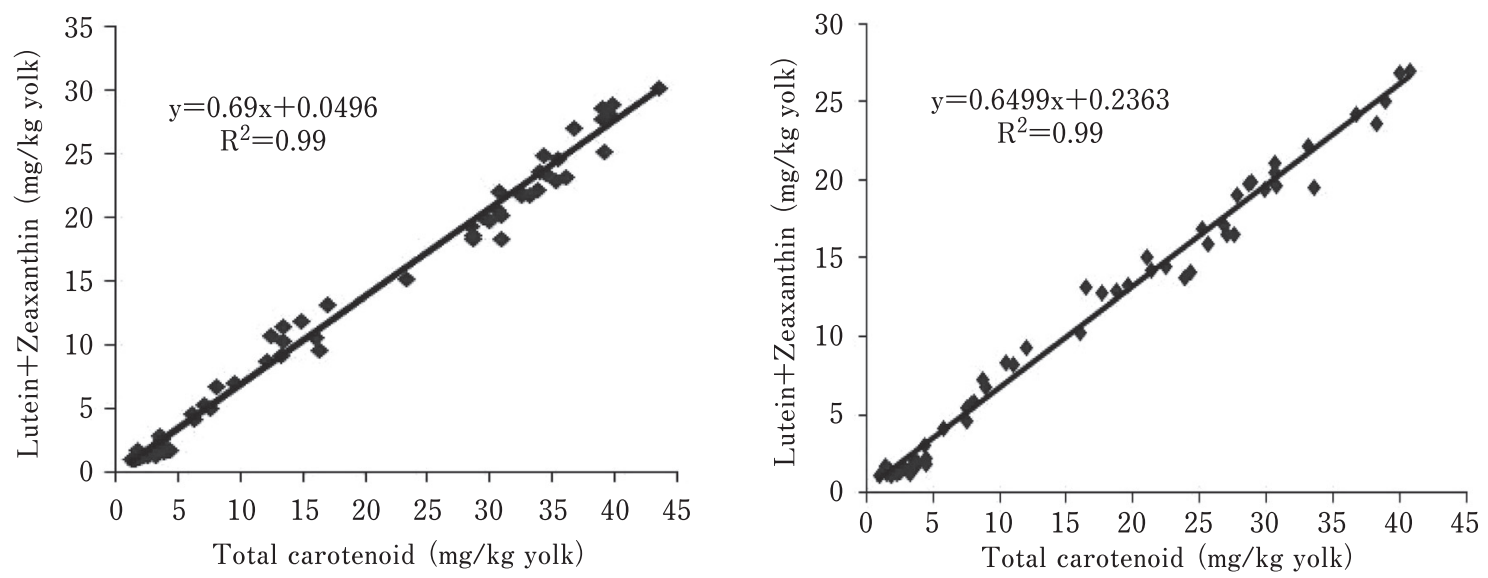

Fig. 1. Relationship between total carotenoid and Lutein + zeaxanthin content of egg yolk in marigold group (left) and oleoresin group (right).

Table 3. RYCF score, lightness, redness and yellowness of egg yolk obtained after marigold and oleoresin supplementation

(a) Marigold group (80 $\mathrm{mg}$ lutein/kg feed)*

(b) Oleoresin group (40 mg lutein/kg feed)*

\begin{tabular}{ccccc|cccc}
\hline \hline Days & $\begin{array}{c}\text { RYCF } \\
\text { score }\end{array}$ & $\begin{array}{c}\text { Lightness } \\
\left(\mathrm{L}^{*}\right)\end{array}$ & $\begin{array}{c}\text { Redness } \\
\left(\mathrm{a}^{*}\right)\end{array}$ & $\begin{array}{c}\text { Yellowness } \\
\left(\mathrm{b}^{*}\right)\end{array}$ & $\begin{array}{c}\text { RYCF } \\
\text { score }\end{array}$ & $\begin{array}{c}\text { Lightness } \\
\left(\mathrm{L}^{*}\right)\end{array}$ & $\begin{array}{c}\text { Redness } \\
\left(\mathrm{a}^{*}\right)\end{array}$ & $\begin{array}{c}\text { Yellowness } \\
\left(\mathrm{b}^{*}\right)\end{array}$ \\
\hline 1 & $2.2 \pm 0.3^{\mathrm{a}}$ & $56.1 \pm 1.9^{\mathrm{a}}$ & $-5.14 \pm 0.37^{\mathrm{a}}$ & $17.7 \pm 1.2^{\mathrm{a}}$ & $2.0 \pm 0.3^{\mathrm{a}}$ & $56.7 \pm 2.8^{\mathrm{ab}}$ & $-5.29 \pm 0.43^{\mathrm{a}}$ & $18.6 \pm 1.41^{\mathrm{a}}$ \\
7 & $5.6 \pm 1.3^{\mathrm{c}}$ & $53.0 \pm 3.9^{\mathrm{a}}$ & $-2.75 \pm 1.15^{\mathrm{c}}$ & $21.8 \pm 4.0^{\mathrm{c}}$ & $4.9 \pm 0.6^{\mathrm{d}}$ & $54.7 \pm 3.1^{\mathrm{b}}$ & $-3.13 \pm 1.27^{\mathrm{b}}$ & $23.1 \pm 2.18^{\mathrm{c}}$ \\
14 & $8.4 \pm 0.3^{\mathrm{d}}$ & $53.2 \pm 2.3^{\mathrm{a}}$ & $0.09 \pm 0.83^{\mathrm{b}}$ & $20.0 \pm 1.5^{\mathrm{abc}}$ & $7.4 \pm 0.5^{\mathrm{b}}$ & $54.9 \pm 2.3^{\mathrm{b}}$ & $-0.48 \pm 0.83^{\mathrm{d}}$ & $20.0 \pm 1.96^{\mathrm{a}}$ \\
21 & $8.3 \pm 0.5^{\mathrm{d}}$ & $53.3 \pm 1.5^{\mathrm{a}}$ & $-0.09 \pm 0.49^{\mathrm{b}}$ & $20.9 \pm 1.6^{\mathrm{bc}}$ & $6.8 \pm 0.5^{\mathrm{bc}}$ & $55.2 \pm 1.9^{\mathrm{b}}$ & $-1.14 \pm 0.98^{\mathrm{cd}}$ & $22.7 \pm 1.96^{\mathrm{bc}}$ \\
28 & $6.0 \pm 0.6^{\mathrm{c}}$ & $55.6 \pm 2.9^{\mathrm{a}}$ & $-2.54 \pm 0.61^{\mathrm{c}}$ & $21.0 \pm 1.3^{\mathrm{abc}}$ & $5.7 \pm 0.8^{\mathrm{cd}}$ & $57.5 \pm 1.9^{\mathrm{ab}}$ & $-2.69 \pm 0.55^{\mathrm{bc}}$ & $22.1 \pm 1.19^{\mathrm{abc}}$ \\
35 & $2.5 \pm 0.8^{\mathrm{a}}$ & $55.7 \pm 4.7^{\mathrm{a}}$ & $-3.99 \pm 0.34^{\mathrm{d}}$ & $18.0 \pm 1.6^{\mathrm{ab}}$ & $3.0 \pm 0.9^{\mathrm{a}}$ & $60.0 \pm 4.2^{\mathrm{ab}}$ & $-4.1 \pm 0.74^{\mathrm{ab}}$ & $19.5 \pm 2.48^{\mathrm{ab}}$ \\
42 & $1.8 \pm 0.3^{\mathrm{a}}$ & $57.3 \pm 2.6^{\mathrm{a}}$ & $-4.55 \pm 0.49^{\mathrm{da}}$ & $18.5 \pm 1.3^{\mathrm{abc}}$ & $1.9 \pm 0.1^{\mathrm{a}}$ & $61.2 \pm 3.9^{\mathrm{a}}$ & $-4.7 \pm 0.22^{\mathrm{ab}}$ & $19.4 \pm 0.53^{\mathrm{ab}}$ \\
\hline
\end{tabular}

a, b, c, d Values with the different superscripts in the same column differ significantly $(P<0.05)$

* Number of eggs from marigold group is 68 (number of eggs in day 1, 7, 14, 21, 28, 35, 42 is 14, 13, 14, 12, 5, 5, 5, respectively) and number of eggs from oleoresin group is 60 (number of eggs in day1, 7, 14, 21, 28, 35, 42 is 14, 11, 14, 11, 3, 4, 3, respectively).
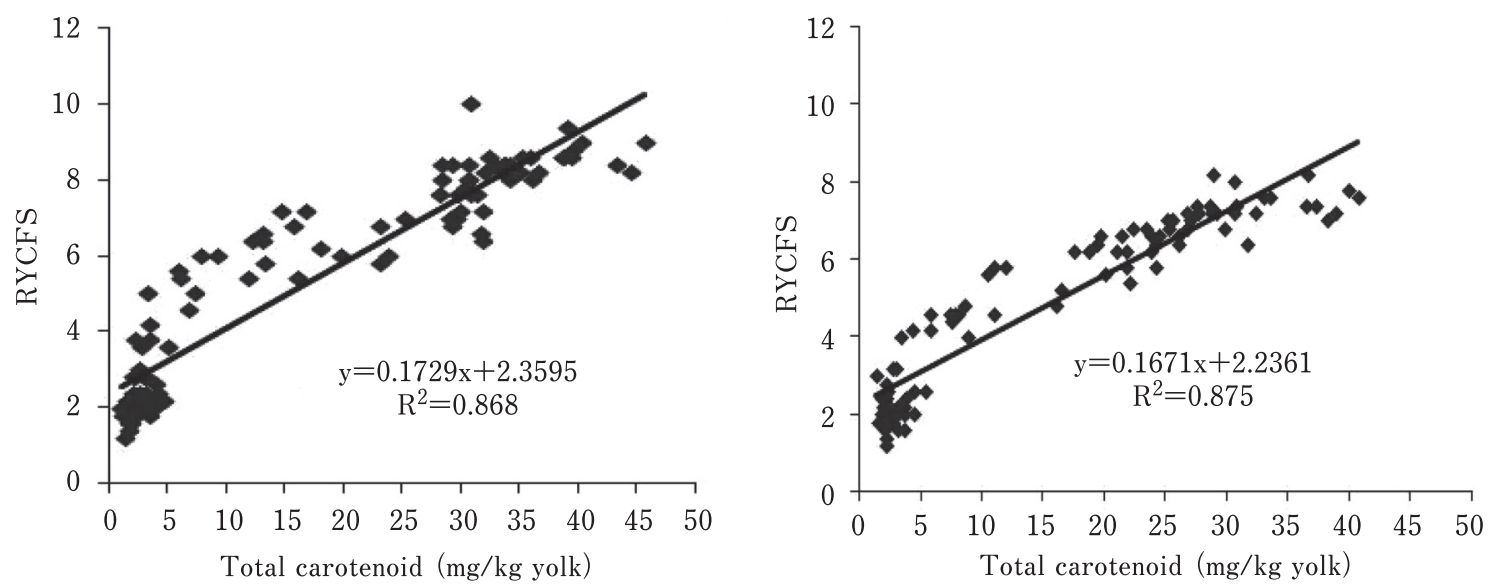

Fig. 2. Relationship between RYCF score and total carotenoid of egg yolk in marigold group (left) and oleoresin group (right). 

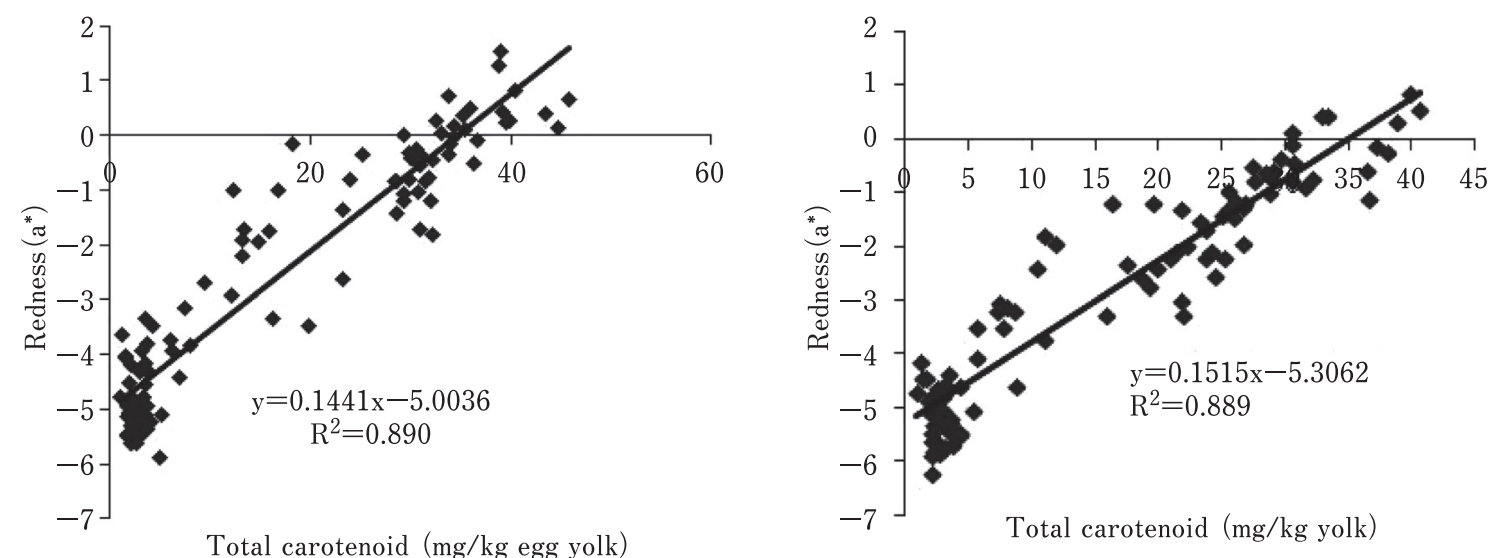

Fig. 3. Relationship between redness (a*) and total carotenoid of egg yolk in marigold group (left) and oleoresin group (right).
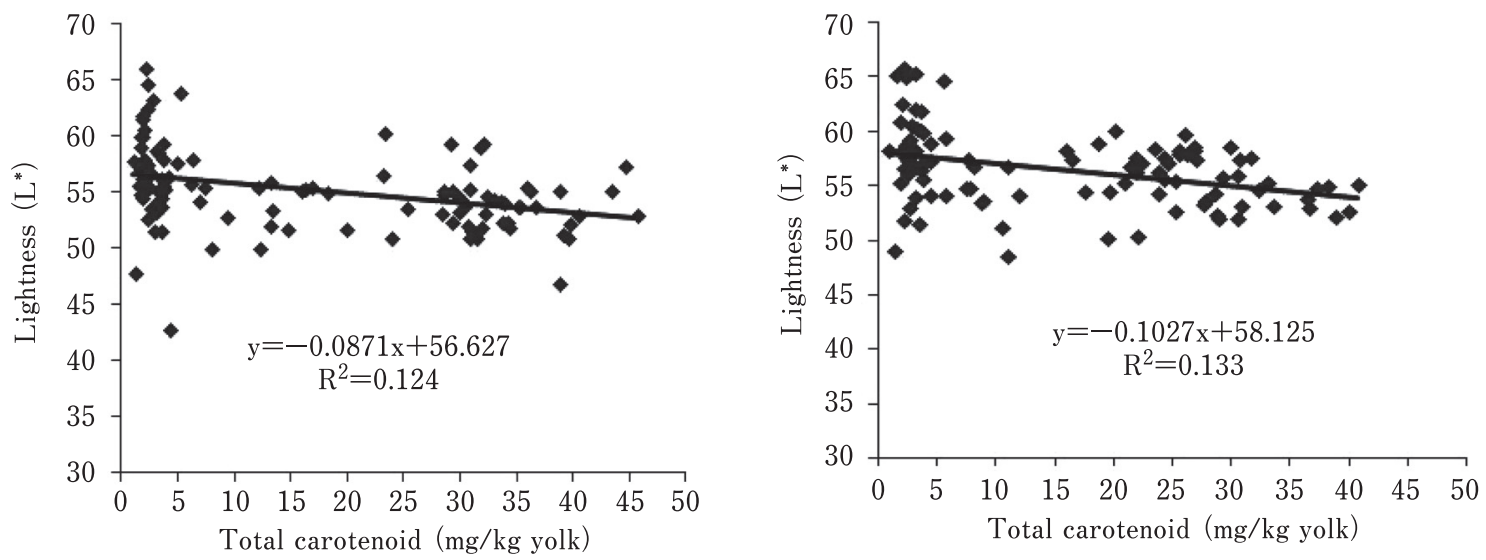

Fig. 4. Relationship between lightness $\left(L^{*}\right)$ and total carotenoid of egg yolk in marigold group (left) and oleoresin group (right).

b). Lightness $\left(\mathrm{L}^{*}\right)$ and yellowness $\left(\mathrm{b}^{*}\right)$ were found to be higher in the oleoresin-supplemented group (Fig. 3). Thus, this difference is related to the total carotenoid or lutein content in feed as well as in the egg.

The RYCF scores follow the trend of the total carotenoid or lutein content in egg yolk (Table 2 and 3). Corresponding with an increase in total carotenoid content, the RYCF score immediately increased within 14 days after supplementation of lutein and the decrease in the RYCF score followed a similar pattern as documented for lutein content. Similar increasing trends were also observed for redness, but the variations were not quite distinct once higher amounts of lutein were accumulated in the egg yolk. Yellowness and lightness decreased with the increase in lutein content in egg yolk. Both marigold- as well as oleoresin-supplemented groups showed similar trends with regard to impact on colour characteristics.

As already mentioned, the total carotenoid content of egg yolks reflects the lutein content since the zeaxanthin content is negligible. Therefore, a positive relationship between the RYCF score $(P<0.05)$ and lutein content in yolk was derived from the data for both groups. The regression coefficient $\left(\mathrm{R}^{2}\right)$ between total carotenoid content and $\mathrm{RYCF}$ score amounted to 0.87 for both groups (Fig. 2). With reference to the RYCF score, redness could also be positively correlated with the lutein concentration of egg yolk obtained for both groups $(P<0.05$; Fig. 3). The regression coefficient $\left(\mathrm{R}^{2}\right)$ between total carotenoid content and redness was 0.89 for both groups. Consequently, it appears that the RYCF score depends upon the redness of the yolk owing to presence of lutein. Total carotenoid or lutein content had an insignificant relationship $\left(\mathrm{R}^{2}=0.13\right)$ with lightness found in both of the feeding groups (Fig. 4). Similarly, yellowness also could not be correlated with the lutein concentration, with $\mathrm{R}^{2}$ value of 0.059 (Fig. 5). 

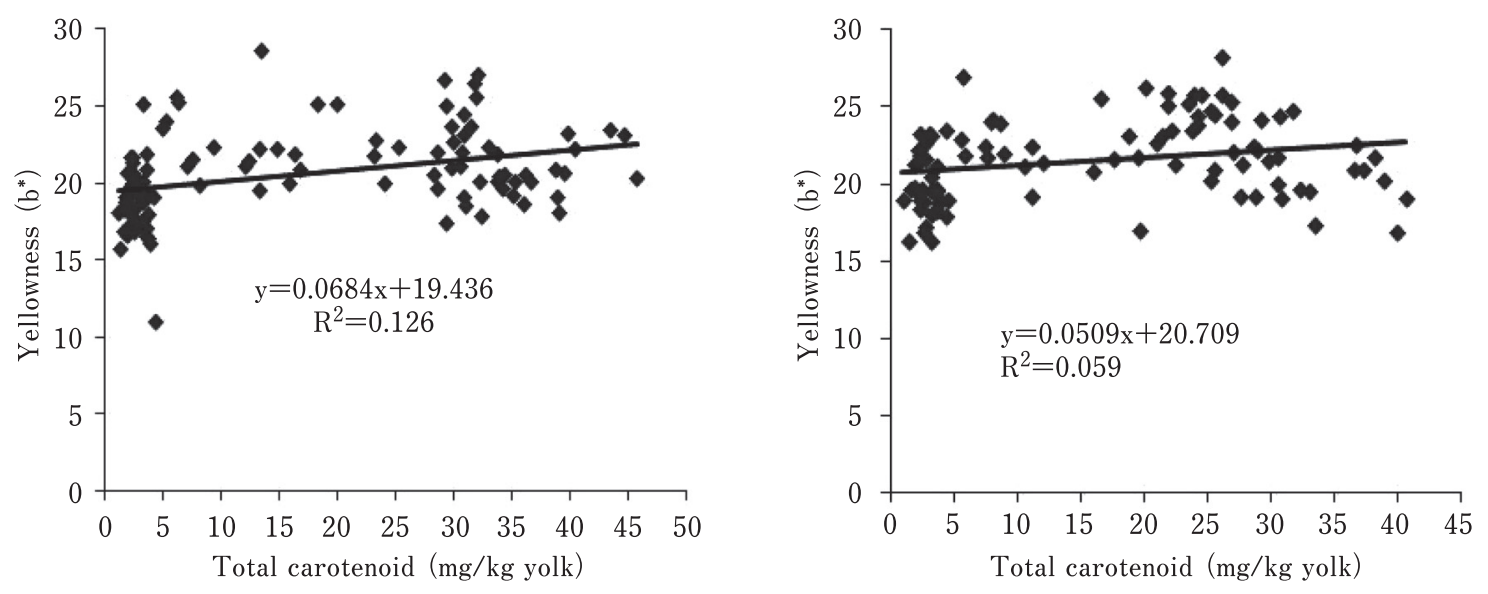

Fig. 5. Relationship between yellowness $\left(b^{*}\right)$ and total carotenoid of egg yolk in marigold group (left) and oleoresin group (right).

\section{Discussion}

In this study, the egg yolks showed the highest lutein content within 14 days of feed supplementation and then declined slightly, which is in agreement with other findings. These studies showed that lutein-depleted chicken receiving lutein-enriched diets experienced the maximum digestibility during initial days but thereafter decreased gradually (Garmendia, 1981).

Many studies have also documented the effect of dietary lutein supplementation and its accumulation in egg yolks, and have found a positive relationship between the two factors (Leeson et al., 2004; Adabi, 2010). Studies indicating a positive relationship between the RYCF and $a^{*}$ value in egg yolk owing to an increased level of total carotenoids added to feed (Kljak et al., 2012) have also revealed similar trends to the present research. It should also be mentioned in this context that hens are not able to synthesize colour pigments but have the ability to transport pigments from the ingested feed to the yolk. Therefore, the carotenoid profiles of egg yolks reflect the supplementation content of diets (Karadas et al., 2006).

Egg yolk colour has been previously shown to be improved by increasing contents of the yolk carotenoid lycopene with corresponding diet supplementation (Sahin et al., 2008), thus revealing similar findings to the present study although the carotenoid types are dissimilar. In addition, strong correlations observed between colour value $\mathrm{a}^{*}$ and total carotenoid content $\left(\mathrm{R}^{2}=0.91\right)$ and colour value $\mathrm{b}^{*}$ with lutein $\left(\mathrm{R}^{2}=0.87\right)$ were reported for pumpkin (Itle and Kabelka, 2009). Therefore, it can be concluded that the carotenoids present in other food substances may also correspond to the findings of the present research.

A negative correlation between $\mathrm{L}^{*}$ and certain carotenoids would be expected because any increase in pigment would increase the darkness and thereby decrease $\mathrm{L}^{*}$. The colour value $a^{*}$ (colour direction in red or green) was strongly cor- related with total carotenoid content $\left(\mathrm{R}^{2}=0.89\right)$. Consequently, a strong positive correlation was observed for both RYCF score and the redness value owing to presence of lutein/total carotenoid. Only a weak correlation can be observed between yellowness and lutein content. Francis (1962) evaluated cultigens of Cucurbita maxima and Cucurbita moschata and identified moderate to strong correlations between $\mathrm{L}^{*}, \mathrm{a}^{*}$ and $\mathrm{b}^{*}$ with total carotenoid content. Seroczynska et al. (2006) reported poor to fair correlations between $\mathrm{L}^{*}, \mathrm{a}^{*}$ and $\mathrm{b}^{*}$ with total carotenoid content and poor to fair correlations between $\mathrm{L}^{*}, \mathrm{a}^{*}$ and $\mathrm{b}^{*}$ with $\beta$ carotene. The strongest linear relationship in our study was found between $\mathrm{a}^{*}$ and total carotenoid content $\left(\mathrm{R}^{2}=0.91 ; \mathrm{R}^{2}\right.$ $=0.83)$. This finding is similar to that in a report by Reeves (1987), which found comparable correlations and strengths between $\mathrm{a}^{*}$ and total carotenoid content $\left(\mathrm{R}^{2}=0.91\right)$. Therefore, lutein content appears to be responsible for increasing RYCF score and redness of egg yolk, but may not affect lightness and yellowness, for which the source of lutein seems to be not relevant.

\section{Conclusion}

Increasing lutein content in egg yolks, as determined by HPLC, correlates strongly with the amount of carotenoids determined by iCheck, reflecting a very strong relationship between the two methods $\left(\mathrm{R}^{2}=0.99\right)$. The total carotenoid content present in the egg yolks primarily reflects the lutein content. Lutein content has a promising relationship with RYCF score and redness $\left(\mathrm{a}^{*}\right)$ of egg yolk $\left(\mathrm{R}^{2}=0.88\right)$, but does not influence the lightness $L^{*}\left(R^{2}=0.12\right)$ and yellowness $b^{*}\left(R^{2}=0.12\right)$ of egg yolk. These close associations allow for accurate indirect selection of eggs that are higher in lutein content when a high score for RYCF and redness ( $\left.\mathrm{a}^{*}\right)$ is given.

\section{Acknowledgments}

The authors deeply acknowledged the Alexander von 
Humboldt Foundation, Germany for financial support to the first author as a postdoctoral fellowship as well as financial support to the host institute.

\section{References}

Adabi SHG, Kamali MA, Davoudi J, Cooper RG and Hajbabaei A. Quantification of lutein in egg following feeding hens with a lutein supplement and quantification of lutein in human plasma after consumption of lutein enriched eggs. Archiv für Geflügelkunde, 74: 158-163. 2010.

Arias R, Lee TC, Logendra L and Janes H. Correlation of lycopene measured by HPLC with the $L^{*}, a^{*}, b^{*}$ color readings of a hydroponic tomato and the relationship of maturity with color and lycopene content. Journal of Agriculture and Food Chemistry, 48: 1697-1702. 2000.

Ameny MA and Wilson PW. Relationship between Hunter color values and $b$-carotene contents in white fleshed African sweet potatoes (Ipomoea batatas Lam). Journal of Science Food and Agriculture, 73: 301-306. 1997.

Bone RA, Landrum JT, Fernandez L and Tarsis SL. Analysis of the macular pigment by HPLC: retinal distribution and age study. Investigative Ophthalmology \& Visual Science, 29: 843-9. 1988.

Britton G. Structure and properties of carotenoids in relation to function. FASEB Journal, 9: 1551-8. 1995.

Francis FJ. Relationship between flesh color and pigment content in squash. Proceedings of American Society of Horticultural Science, 81: 408-414. 1962.

Garmendia MM, Alonso A and Gomez R. Digestibility and fate of lutein in chicken. Camparative Biochemistry and Physiology, 70: 619-62. 1981.

Handelman GJ, Dratz EA, Reay CC and van Kuijk FJGM. Carotenoids in the human macula and whole retina. Investigative Ophthalmology \& Visual Science, 29: 850-5. 1988.

Handelman GJ, Nightingale ZD, Lichtenstein AH, Lichtenstein AH, Schaefer EJ and Blumberg JB. Lutein and zeaxanthin concentrations in plasma after dietary supplementation with egg yolk. American Journal of Clinical Nutrition, 70: 247-51. 1999.

Hamilton PB. The use of high performance liquid chromatography for studying pigmentation. Poultry Science, 71: 718-724. 1992.

Hunter, RS. Photoelectric color-difference meter. Proceedings of the Winter Meeting of the Optical Society of America, 38: 661. 1948a.

Hunter, RS. Accuracy, precision and stability of new photo-electric color-difference meter. Proceedings of the Thirty-Third Annual Meeting of the Optical Society of America, 38: 1094. 1948b.

Islam KMS and Schweigert FJ. Comparison of three spectrophotometric methods for analysis of egg yolk carotenoids. Food Chemistry, 172: 233-237. 2015.

Itle RA and Kabelka1 EA. Correlation between L*a*b* color space values and carotenoid content in pumpkins and squash
(Cucurbita spp.). HortScience, 44: 633-637. 2009.

Karadas F, Grammendis E and Surai PF. Effects of carotenoids from lucerne, marigold and tomato on egg yolk pigmentation and carotenoid composition. British Poultry Science, 47: 561-566. 2006.

Karunajeeva H, Hughes RS, McDonald MW and Shenstone FS. A review of factors influencing pigmentation of egg yolks. World's Poultry Science Journal, 40: 52-65. 1984.

Kljak K, Drdić M, Karolyi D and Grbeša D. Pigmentation effi ciency of croatian corn hybrids in egg production. Croatian Journal of Food Technology, Biotechnology and Nutrition, 7: 23-27. 2012.

Krinsky N. Actions of carotenoids in biological systems. Annual Review of Nutrition, 13: 561-87. 1993.

Leeson S and Caston L. Enrichment of eggs with lutein. Poultry Science, 83: 1709-1712. 2004.

Landrum JT, Bone RA and Kilburn MD. The macular pigment: a possible role in protection from age-related macular degeneration. Advance Pharmacology, 38: 537-56. 1997.

Mayne ST. Beta-carotene, carotenoids, and disease prevention in humans. FASEB Journal, 10: 690-701. 1996.

Minitab. Minitab Release 12.1. Minitab Reference Manual. Minitab Inc., State College, PA. 1998.

NRC. Nutrient requirements of poultry. Ninth Revised Edition, 1994, National Academy Press, Washington D.C. 1994.

Reeves MJ. Re-evaluation of capsicum color data. Journal of Food Science, 52: 1047-1049. 1987.

Seddon JM, Ajani UA, Sperduto R, Hiller R, Blair N, Burton TC, Farber MD, Gragoudas ES, Haller J, Miller DT, Yannuzzi LA and Willett W. Dietary carotenoids, vitamins A, C, and E, and advanced age-related macular degeneration. Eye Disease CaseControl Study Group. Journal of American Medical Association, 272: 1413-20. 1994.

Schweigert F, Schierle J and Hurtinne A. Analysis of total carotenoids in egg yolk - a fast and laboratory-independent assay. In: Proceedings of XIII th European Poultry Conference France, 23-27 August, 2010. S31 - Egg Quality. pp. 193-146. 2010.

Sahin N, Akdemir F, Orhan C, Kucuk O, Hayirli A and Sahin K. Lycopene-enriched quail egg as functional food for humans. Food Research International, 41: 295-300. 2008.

Seroczynska A, Korzeniewska, A, Sztangret-Wisniewska J, NiemirowiczSzczytt K and Gajewski M. Relationship between carotenoid content and flower or fruit flesh colour of winter squash (Cucurbita maxima Duch.). Horticulture, 18: 51-61. 2006.

Steel RGD, Torrie JH. Principle and Procedures of Statistics, Mc. Graw Hill Book Co., New York, U.S.A. 1990.

Vailleumier JP. The Roche yolk color fan - An instrument for measuring yolk color. Poultry Science, 48: 767-779. 1969.

Williams WD. Origin and impact of color on consumer preference for food. Poultry Science, 71: 744-746. 1992. 